\title{
Çok Güzel Hareketler 2 ve Güldür Güldür Show İsimli Komedi Programlarında Toplumsal Cinsiyet Rollerinin Temsili ${ }^{1}$
}

Başvuru Tarihi: $\quad 10.11 .2020$ Yayın Kabul Tarihi: $\quad$ 19.12.2020 Yayınlanma Tarihi: $\quad 30.12 .2020$

\author{
Erdem Türkavci ${ }^{2}$ \\ Gelişim Üniversitesi \\ eturkavci@gelisim.edu.tr \\ ORCID: 0000-0001-5264-8552 \\ Huriye Kuruoğlu ${ }^{3}$ \\ Ege Üniversitesi \\ huriye.kuruoglu@ege.edu.tr \\ D) ORCID: 0000-0003-2563-2445
}

\section{ÖZET}

Toplumsal cinsiyet kavramının inşasında toplum ve kültür kadar medyanın da etkisi oldukça büyüktür. Yaygın bir kitle iletişim aracı olan televizyonda yer alan tüm programlar var olan toplumsal rollerin yeniden üretilmesi açısından büyük bir rol oynamaktadır. Bu bağlamda, çok geniş bir izleyici kitlesi olan dizi ve pek çok program, toplumsal cinsiyetin temsili konusunda inceleme alanı sunmaktadır. Televizyonda yayınlanan komedi programları da bu temsil alanlarından biridir. Komedi türünün güldürme ve eğlendirme işlevlerine ek olarak, toplumsal her türlü konuyu eleştirel ele alabilmesi, toplumsal cinsiyet rollerinin komedi programlarındaki temsilinin sorgulanmasını önemli hale getirmektedir. Bu çalışmadaki amaç da televizyonda yüksek izlenme oranlarına sahip Çok Güzel Hareketler 2 ve Güldür Güldür Show isimli komedi programlarındaki toplumsal cinsiyet rollerinin temsilini incelemektir. Yöntem olarak içerik analizinin kullanıldığı araştırmada amaçlı örneklem doğrultusunda Çok Güzel Hareketler 2 ve Güldür Güldür Show isimli programların 2019-2020 sezonundan toplamda 16 skeç değerlendirme konusu edilmiş; skeçlerdeki kadın, erkek, LGBTIQ tiplerin sayıları ve temsilleri incelenmiştir. Canlandırılan tipler üzerinden yapılan çözümleme sürecinde elde edilen bulgular, skeçlerde kadın-erkek kimliklerinden sayıca erkek kimliğine ağırlık verildiğini, LGBTIQ kimliklerin göz ardı edildiğini ortaya koymakta ve toplumsal cinsiyet kalıp yargılarının yeniden üretildiğini göstermektedir.

Anahtar Kelimeler: Toplumsal Cinsiyet, Televizyon, Komedi, Durum Komedisi, Televizyon Komedisi Programı.

\footnotetext{
1 Bu çalışma, Aydın Adnan Menderes Üniversitesi'nin hazırladığı “3 ${ }^{\text {rd }}$ Cultural Informatics, Communication \& Media Studies Conference” (20-22 Nisan 2020, Aydın)'ta sözlü bildiri olarak sunulmuştur. Sempozyum kitapçığında özeti ile yer almış, tam metin olarak ilk kez "Uluslararası Medya ve İletişim Araştırmaları Hakemli Dergisi (MEDIAJ)"nde yayınlanmıştır.

${ }^{2}$ Araştırma Görevlisi. İstanbul Gelişim Üniversitesi.

3 Profesör Doktor. Ege Üniversitesi.
} 


\title{
Representation of Gender Roles in the Television Comedies Çok Güzel Hareketler 2 and Güldür Güldür Show ${ }^{4}$
}

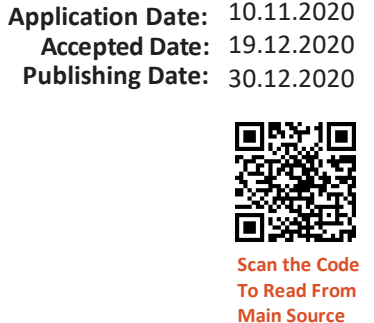

Application Date: 10.11 .2020 Accepted Date: 19.12 .2020 o Read From Main Source

\author{
Erdem Türkavci ${ }^{5}$ \\ Gelişim Üniversitesi \\ eturkavci@gelisim.edu.tr \\ iD ORCID: 0000-0001-5264-8552 \\ Huriye Kuruoğlu ${ }^{6}$ \\ Ege Üniversitesi \\ huriye.kuruoglu@ege.edu.tr \\ ORCID: 0000-0003-2563-2445
}

\begin{abstract}
Media greatly affect the construction of gender, just as much as the society and culture do, and even more so in recent years. All programs on television, a widespread mass media, play a big role in reproducing existing social roles. In this sense, TV series as well as many other programs that have a wide audience offer a field of study on the representation of gender. One of these areas of representation is comedy programs. In addition to their function as humor and entertainment, comedy programs are also able to deal with any social issue critically, which makes questioning the representation of gender roles in comedy programs important. This study aims to examine the representation of gender roles in the comedy programs, Çok Güzel Hareketler 2 and Güldür Güldür Show, both of which have high ratings on television. Using content analysis as its method, the study evaluates 16 sketches from these two programs (season 2019-2020) chosen through purposeful sampling method, in terms of the number and representation of women, men, and LGBTIQ individuals. The findings obtained in the process of character analysis reveal that male identity is numerically emphasized more than female identity, that LGBTIQ individuals are largely ignored and that gender stereotypes are recreated.
\end{abstract}

Keywords: Gender, Television, Comedy, Sitcom, Television Comedy.

\footnotetext{
4 This study was presented at the " $3^{\text {rd }}$ Cultural Informatics, Communication and Media Studies Conference" (20-22 April 2020, Aydın) prepared by Aydın Adnan Menderes University. Its abstract was published in the symposium booklet. The full text was first published in the "International Refereed Journal of Media and Communication Research (MEDIAJ)"

${ }^{5}$ Research Assistant. İstanbul Gelişim University.

${ }^{6}$ Professor. Ege University.
} 


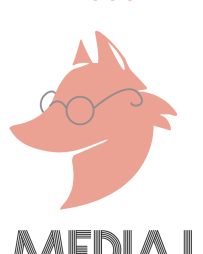

\section{Giriş}

Toplumsal cinsiyet kavramı, bireyin biyolojik özelliği bakımından kadın ya da erkek olduğunu açıklayan cinsiyet kavramından farklı olarak, kadın ve erkek cinsiyetleri için toplum ve kültür tarafından inşa edilen anlam ve beklentileri açıklamaktadır. Ancak toplumsal cinsiyet kavramının inşasında ve inşanın sürdürülmesinde medyanın da oldukça önemli bir rolü bulunmaktadır. Televizyonda yayınlanan haber, dizi, program vb. türden her içerik, toplumsal cinsiyetin kamuoyundaki inşasında varlık gösterdiği kadar onun temsili konusunda da araştırmacılara inceleme alanı sunmaktadır. Son dönemde yerli televizyon kanallarının prime time kuşağında komedi programlarının ön plana çıkması ve bu programların geniş bir izleyici kitlesi tarafından seyredilmesi, toplumsal cinsiyet rollerinin temsili konusunda önemli bir inceleme alanı sunmaktadır. Araştırmanın amacı, bu programlardan -2019-2020 sezonundan- örneklem olarak seçilen Çok Güzel Hareketler 2 ve Güldür Güldür Show isimli komedi programlarındaki toplumsal cinsiyet rollerinin temsilini incelemektir. Yöntem olarak içerik analizinin kullanıldığı araştırmada, amaçlı örneklem doğrultusunda her iki programdan ikişer skeç grubu oluşturulmuş; toplam 16 skeç incelenmiştir. Her iki programda hemen hemen her hafta bir tane bölümlü skeç sahnelendiği için örneklem oluşturulurken skeçlerden bir tanesinin bölümlü skeç olmasına dikkat edilmiştir. Bu tercihin ortaya çıkmasındaki itici güç, bölümlü skeçlerde yer alan kadın, erkek ve LGBTIQ rollerin seri içindeki değişimini sorgulayarak araştırmaya katkı sağlamaktır. Araştırmada örneklem olarak seçilen skeçlerde kaç kadın, erkek ve LGBTIQ tipin olduğu belirlendikten sonra bu kimliklerin nasıl temsil edildiği, skeçlerde öne çıkan mesajların neler olduğu (toplumsal cinsiyet kavramı üzerinden eleştirinin getirilip getirilmediği, ataerkilliğin ya da homofobik söylemin yeniden üretilip üretilmediği) sorgulanmıştır. Araştırmanın temel savı, programlardaki skeçlerde kadın-erkek kimliklerinden sayıca erkek kimliğine ağılık verildiği, LGBTIQ kimliklerin göz ardı edildiği ve toplumsal cinsiyet kalıp yargılarının yeniden üretildiğidir.

\section{Cinsiyet ve Toplumsal Cinsiyet Kavramı}

Tarihsel süreçte bütün toplumlar, kadın ve erkek kimliğine ilişkin belirli sınırlar çizmiştir. Kadın ve erkeklere atfedilen görev ve roller de dönemin toplumsal yapısına göre şekillenmiş ya da değişiklik göstermiştir. Bu bağlamda toplumsal cinsiyet kavramı, cinsiyet kavramından farklı olarak, cinsiyet hiyerarşisini de açıklayan bir kavram olarak karşımıza çıkar (Kandiyoti, 1997, s.169). Toplumsal cinsiyet kavramında "cinsiyet" kelimesi yer aldığı için öncelikle bu kelimenin açıklanması gerekmektedir. Kavramlar arasındaki anlam farklılı̆ın ortaya konmasındaki temel neden, cinsiyet kavramı ve rolleri üzerine günümüzde daha çok araştırma, kavram ve yaklaşımın ortaya konmasıdır.

İngilizce'deki "sex" karşılı̆ı ile cinsiyet kavramı, kadın ya da erkek olmanın biyolojik yönünü ifade eden demografik bir sınıflandırmadır. İnsanların nüfus cüzdanlarında yazan cinsiyet bu terimin anlamı için uygundur (Dökmen, 2009, s.19-20). TDK, cinsiyet kavramı için "Bireye, üreme işinde ayrı bir rol veren ve erkekle dişiyi ayırt ettiren yaradıış özelliği, eşey, cinslik, seks." tanımını vermektedir (TDK, 2019). Bu noktada, cinsiyet kavramından yola çıkılarak cinsiyet kimliği ile cinsel kimlik kavramları arasındaki ayrıma değinilmelidir. Zira, cinsiyet kimliği kişinin kendini kişilik ve davranış olarak belli bir cinsiyette hissetmesi ve ona göre davranmasıdır. Cinsel kimlik ise, daha çok tercih edilen cinsel yönelimi ifade etmek üzere kullanılır ve heteroseksüellik, homoseksüellik, biseksüellik, transeksüellik ya da aseksüellik olarak sınıflanması mümkündür (Dökmen, 2009, s.27).

Cinsiyet kavramı için günümüzde biyolojik farklılıklardan yola çıkılarak basit bir kadın-erkek ayrımı yapılmasından farklı tanımlar yapılmaya başlanmıştır. Zira, erkeklik ve kadınlık 


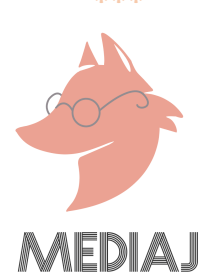

kavramlarına atfedilen özellikler, kamuoyu nezdinde kabul görmüş rollerin içerisine sıkışmıştır. Bu açıdan cinsiyetin biyolojik boyutunu işaret eden yaklaşım, yerini toplumsal cinsiyet anlayışına bırakmıştır. Kadın ve erkek artık, sadece toplumsal paradigmanın kendileri için belirlediği edimleri yerine getirmekle sorumlu tutulmaktadır (Caner, 2004, s. 40-42).

Ingilizce'de cinsiyet kavramının toplumsal boyutunu işaret eden gender, Türkçe'de 'toplumsal cinsiyet' kavramı ile açıklanmaktadır. Toplumsal cinsiyet, kadın veya erkek olmaya toplumun ve kültürün yüklediği anlamları ve beklentileri ifade eder. ${ }^{7}$ Kültürel bir yapıyı karşılar ve genellikle bireyin biyolojik yapısıyla ilişkili bulunan psikolojik özelliklerini de içerir (Dökmen, 2009, s.20). Connell'e göre toplumsal cinsiyet psikolojisinde en yaygın anlayış, birer grup olarak kadın ve erkeklerin farklı kişilik özelliklerine sahip olduğunun varsayımıdır. Kadın ve erkekler yaradıış, karakter, düşünüş biçimleri, dış görünüşleri, yetenek ve tüm kişilik yapıları açısından birbirlerinden farklıdır. Connell, kadın ve erkek arasındaki farklılı̆ı belirten bu durumu, "cinsel karakter" kavramıyla açıklamaktadır (Connell, 1998, s.225). Yalova'nın ifadesiyle biyolojik cinsiyetimiz, genellikle değişmeyen bir nitelik olarak kalırken toplumsal cinsiyet öğretisine dayalı toplumsal cinsiyet kalıpları, içinde yaşanan toplumun gelişmişlik düzeyine, toplum felsefesinin dünyayı algılayış biçimine, zamana ve mekâna göre değişiklik göstermektedir (Yalova, 2002, s.16). Benzer şekilde Saraç da toplumsal cinsiyetin zamana, kültüre, aileye göre değişkenlik gösterebileceğini ifade ederek cinsiyetin doğal bir nitelik; toplumsal cinsiyetin ise insan icadı olduğunu vurgular (Saraç, 2013, s.27). Connell'e göre toplumsal cinsiyet kuramları, insanlar arasındaki bire bir ilişkiler ya da bir bütün olarak toplum üzerinde yoğunlaşmaktadır. Connell'in ifadesiyle; "Günlük yaşamımızın büyük bir bölümünü, bir bütün olarak toplumla ilişkide yayılmak veya bire bir ilişkiye sarılmak yerine ev, işyeri veya otobüs kuyruğu gibi ortamlarda geçiririz." (Connell, 1986, s.165). Connell, toplumsal cinsiyet rejimleri ve toplumsal cinsiyet düzeninin kısaca kurumlar, aile, devlet ve sokak tarafından şekillendiğini ifade etmektedir (Connell, 1998, s.165-181). Bunun oluşmasında, yayılmasında ve/veya yeniden üretilmesinde kitle iletişim araçlarının da etkisi büyüktür. Toplumdan topluma değişiklik gösteren cinsiyet rejimleri, etkileşimde olduğu bu sistemler sonucunda karmaşık bir yapıya sahip olur.

Toplumsal cinsiyet kavramı ilk kez, cinse dayalı ayrımların aslında toplumsal olduğunu ifade eden Amerikalı feministler tarafından ortaya konmuştur. Bu kavram, cins ya da cinsel farklılık gibi kavramların kullanımında ima edilen biyolojik determinizmin reddini ifade eder. Kavram aynı zamanda dişilliğin normatif tanımlarının ilişkisel yönünü de vurgulamıştır. Bu yaklaşımda, birbirlerine göre tanımlanan kadın ve erkekler, ayrı ayrı çalışma konusu olamazlar. Zira, kadını anlamak için erkeğe, erkeği anlamak için kadına bakılması gerekmektedir. Scott, Amerikalı feministlerin amacının, toplumsal cinsiyet gruplarının tarihsel süreçteki önemini anlamak olduğunu ifade eder. Amerikalı feministler, cins rollerinin farklı toplumlardaki ve dönemlerdeki kapsamını keşfetmeye, bunun ne anlama geldiğini ortaya koymaya ve toplumsal düzenin devamlılı̆ında ya da değişiminde nasıl işlev gördüklerini açıklamaya çalışılar (Scott, 2007, s.34). Tarihsel süreçte toplumsal yaşama geçilip ticaret ve özel mülkiyet ilişkilerinin gelişmesiyle birlikte iş bölümü düzenlenmeye başlamıştır. Bu süreçte ataerkil sistemin etkisiyle, kadın-erkek, özel alan-kamusal alan ayrımları üretilirken cinsiyetçi iş bölümü de bu ayrımların üzerine inşa edilir. Ev içi ve aile, özel alan; ev dışındaki siyaset, çalışma yaşamı, bilim ve sanat üretiminin

\footnotetext{
${ }^{7}$ Toplumsal cinsiyet, toplum ve kültür tarafından kadın ve erkek cinsel kimliklerine atfedilen anlam ve beklentileri açıklamasına karşın, toplumun aynı zamanda LGBTIQ (lezbiyen, gay, biseksüel, trans, interseks, queer) bireylerden de oluştuğu gerçeği göz ardı edilmemelidir. Bu nedenle çalışmada ele alınan skeçlerde, sadece kadın-erkek cinsel kimliğinin temsili değil; LGBTIQ temsili de incelemeye dahil edilmiştir.
} 


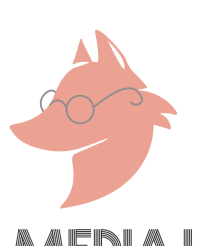

yapıldığı alan ise kamusal alan olarak tanımlanmaktadır. Bu sistemde, kadınlar özel alanla sınırlandırılırken erkekler hem bireysel hem de toplumsal gelişimlerini sağlayabildikleri kamusal alanda etkin olan öznelerdir (Kolay, 2012, s.25-26). Öyle ki kadınlar, tarihin büyük bir bölümünde Kolay'ın ifadesiyle ev içindeki temizlik, yemek pişirme, çamaşır/bulaşık yıkama, ütüleme gibi işleri ve ev içindeki hasta, yaşlı, engelli ve çocuk bakımını üstlenmiştir. Kadınların, geniş ve etkin bir ölçüde çalışma hayatına katılmaya başlamaları 2. Dünya Savaşı sonrasına denk gelmektedir. Ancak bu durum kadınların ev ve ev halkı bakımı sorumluluğunu ortadan kaldırmadığı gibi iş yükünün de artmasına neden olmuştur. Teknolojik gelişmeler, kadınların ev işlerine ayırdığı zamanda düşüş sağlamasına karşın aile içi rollerde değişme olmadığından kadınlar, ev içinde ücretsiz çalışmaya devam etmiştir (Kolay, 2012, s.25).

\section{Toplumsal Cinsiyetin Toplumsallaşması}

Toplumsallaşma, kişinin içinde yer aldığı grubun normlarını, değerlerini, tutumlarını ve karakteristik dilini edinmesi yönündeki etkileşim sürecini açıklamaktadır (Coştu, 2009, s.119). Giddens, insanların toplumsal cinsiyet gerçeğiyle çocukluk döneminde karşılaştığını ifade etmektedir. Giddens'a göre çocuklar kendilerini erkek veya kız olarak tanımlamadan önce başta ebeveynlerinden olmak üzere çevrelerinden çeşitli işaretler alırlar. İki yaşına gelen bir çocuk, toplumsal cinsiyetin ne olduğuna dair dair bilgi edinmeye; kendilerinin ve etrafındaki kişilerin cinsiyetinin ne olduğunu anlamaya başlar. Ancak Giddens'ın ifadesiyle "... çocuklar, beş ya da altı yaşa gelene kadar, kişinin toplumsal cinsiyetinin değişmediğini, herkesin bir toplumsal cinsiyeti olduğunu ve kızlar ile erkekler arasındaki cinsiyet farklııklarının anatomik temelli olduğunu bilmezler" (Giddens, 2012, s.209). Connell'e göre de yeni doğan çocuğun biyolojik bir cinsiyeti vardır ancak çocuk, henüz toplumsal bir cinsiyete sahip değildir. Çocuk büyümeye başladığında cinsiyetine uygun kurallar ve davranış modelleriyle karşılaşır. Aile, medya, arkadaş grubu, okul gibi toplumsallaştırma etkenleri, çocuğun kural ve davranış modellerini sahipleneceği ortamları hazırlar. Connell'in ifadesiyle "bunun sonucunda, normalde belirli bir cinsiyetin toplumsal beklentileriyle örtüşen bir toplumsal cinsiyet kimliği ortaya çıkar." (Connell, 1998, s.255). Connell'e göre cinsel ideolojide, toplumsal pratiğin yapısı doğallaştırma yoluyla çökertilir. Connell, cinsiyete dayalı iş bölümlerinin ve cinsel yönelimlere ilişkin inşa edilen görüşlerin de bu şekilde ortaya çıktığını şu sözleriyle ifade eder:

“...kadınların, aslında matbaa makinelerini çalıştırabildikleri halde, bu makineleri çalışırmaya doğal olarak yetersiz oldukları konusunda, nasıl kandırıldıklarına dikkat çeker. Çocuk bakımındaki iş bölümüne ilişsin tartışmalarda kadınların anneliğe ve çocuklara yönelik doğal arzusu sorgulanmaksızın kabul edilmektedir. ... Heteroseksüel çekim, daima doğal bir şey olarak yorumlanır -zıtların birbirini çekmesi- ve toplumsal olarak yasaklanmış ilişkiler, özellikle de eşcinsellik, "doğal olmayan" bir şey olarak yorumlanır" (Connell, 1998, s.321).

Dökmen ise toplumsallaşma sürecinde "toplumsal cinsiyet farklııkları"nın ortaya çıktığını ifade eder. Toplumsal cinsiyet farklııkları, kız ve erkek çocuklarının kendi kültürleri tarafından cinsiyetleri için uygun bulunan duygu, tutum, davranış ve roller arasındaki farklılıklar olarak açıklanır:

Kadınların daha duyarlı, ilgili ve bakım verici vb. olarak algılanmaları; ev kadını, öğretmen, hemşire vb. olmalarının beklenmesi, ama erkeklerin bağımsız, atılgan, kuvvetli vb. algılanmaları; 


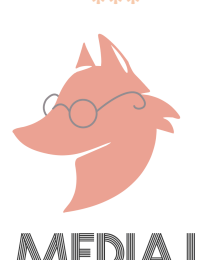

asker, mühendis, tüccar vb. olmalarının beklenmesi toplumsal cinsiyet farklılıklarıdır. ... Bunlar gerçek olmayan farklılıklardır; âdeta toplumun kendi kalıplarını bireye dayatması sonucu oluşurlar (Dökmen, 2007, s.24-25).

Kitle iletişim araçları ve bu araçlardan yayılan iletiler, aykırı örneklerine rastlanmakla birlikte genellikle egemen toplumsal cinsiyet kalıplarını ve tanımlarını yeniden üretmektedir (Kuruoğlu, 2014). Bu bağlamda toplumsal cinsiyetin toplumsallaşması ve toplumsal cinsiyet farklılıkların ortaya çıkması konusunda da kitle iletişim araçlarının etkisi göz ardı edilmemelidir. Geniş kitlelere ulaşması açısından televizyon, toplumsal cinsiyetin toplumsallaşmasında ve toplumsal cinsiyet kalıp yargılarının yeniden üretilmesinde ve pekiştirilmesinde en etkin kitle iletişim araçlarındandır.

\section{Toplumsal Cinsiyet ve Medya}

Medya kavramının sinema, televizyon, radyo, kitap, gazete, dergi vb. iletişim araçlarından oluşması, toplumsal cinsiyet rollerine dair temsil alanlarının genişlemesine neden olduğu kadar bu temsillerin incelenmesi için de araştırmacılara olanak sağlamaktadır. Şener, Çavuşoğlu ve Irklı, toplumsal cinsiyet ve medya üzerine akademik çalışmaları dört başık altında toplamaktadır: Medyanın toplumsal cinsiyet rollerini nasıl temsil ettiğine ilişkin çalışmalar, medyanın farklı kadınlık ve erkeklik biçimlerinin inşasındaki rolü, kadınların ve erkeklerin medya kullanımları/tüketimleri, medyanın ekonomi politiği bağlamında medya sektöründeki ve haber üretimindeki cinsiyetçilik (2020, s.167-180). Medya araçlarının kendi içinde farklı türlere ayrılması/içeriklere sahip olması ve yeni medya kavramının ortaya çıkması, toplumsal cinsiyet ve medya çalışmalarının kapsamını iyiden iyiye genişletmiştir.

Örneğin, televizyon alanında yapılan çalışmalar dizi, haber, program (yarışma programları, reality show'lar, gündüz kuşağı/kadın kuşağı programları, magazin programları) reklam filmleri gibi örneklemlerle karşılık bulmakta ve kadın-erkek temsili, LGBTIQ temsili, çocuk temsili, temsilde adaletsizlik, toplumsal cinsiyet kalıpyargıların yeniden üretimi gibi olguları sorgulamaktadır: İrem İnceoğlu ve Elif Akçalı’nın Televizyon Dizilerinde Toplumsal Cinsiyet Eşitliği Araştırması (2018) isimli TÜsiAD projesi, Mehmet Özdemir'in Türkiye'deki Reklâmlarda Toplumsal Cinsiyet ve Sunum (2010) isimli çalışması, Mehtap Özsoy ve Emine Şeyma Taşdelen'in Pepee Çizgi Dizisinde Toplumsal Cinsiyet Rollerinin Üretimi (2016) isimli çalışması, Devrim Deniz Erol'un Toplumsal Cinsiyet Bağlamında Türkiye Yazılı Basınında Şiddet Haberleri ve Haber Fotoğrafları (2013) isimli çalışması, Pelin Ügümü, Gülten Adalı Aydın, Şükrü Aydın’ın Reklamlarda Lgbti+ Bireylerin Toplumsal Cinsiyet ve Tüketim Kültürü Çerçevesinde Sunumu (2017) çalışması vb. Televizyon gibi geniş kitlelere ulaşan bir medya aracının, sahip olduğu tür ve/veya içeriklerinin araştırma konusu edilmesi, toplumsal cinsiyet rollerinin toplumsallaşma sürecine ilişkin tümevarımcı sonuçların ulaşılmasını sağlamaktadır.

Toplumsal cinsiyet ve medya bağlamında yapılan çalışmalar, medya içeriklerinin sadece toplumsal cinsiyet kalıp yargılarını aktaran değil, aynı zamanda toplumsal cinsiyet eşitsizliğini yeniden üretebilen bir araç olarak konumlandığını, medyadaki hegemonik temsil ve söylem ile medyanın ekonomi politik yapısını da deşifre eder.

\section{Televizyonda Komedinin Dönüşümü}

Komedi, Yunanca'da "bir yerden bir yere gezinip duran, köylü gezgin, köy" anlamına gelen 


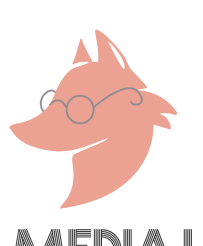

komen-komos-komikos ile "şarkı söylemek" anlamına gelen ado'nun birleşmesinden türetilmiş; kavram, eğlenceli oyunlar oynayan köylü gruplar tarafından kendilerini tanımlamak amacıyla kullanılmıştır (Makal, 2017, s.13). Özünde tiyatro oyun türü olma özelliğiyle Antik çağdan günümüze dek varlığını sürdüren komedi, başlangıçta -özellikle tragedya karşısında- alt sınıfın temsilini sunan ve beğenisine hitap eden bir tür olarak adlandırılmıştır (Eşigül, 2002, s.42). Öyle ki Aristotelese göre; "Komedya daha bayağı insanların taklididir ama kötülüğün her türünü ele almaz, gülünç olanı, yani çirkinliğin belli bir kısmını alır." (Aristoteles, 2018, s.13). Sütcü’nün ifadesiyle de "komedinin düşük düzeyde sanat muamelesi görmesi, kendi içinde bir ikilik barındırır; yüksek sanatlar seviyesine dahil edilmemiştir ancak her zaman düşük düzeyde de olsa bir 'sanat' değeri görmüştür." (Sütcü, 2016, s.3). Ancak komedi, kesiştiği mizah türleri (hiciv, satir, ironi vb.) aracılığıyla bu özeliğinden zaman içerisinde sıyrılarak dönüşüm geçirmiş; üretim açısından belirli bir nitelik kazandığı gibi gerekli değeri de görmüştür. Öyle ki bugün komedi, tiyatrodan sinema ve televizyona kadar pek çok mecrada tercih edilen ve geniş kitlelere ulaşan etkin bir tür olarak karşımıza çıkmaktadır.

Her türlü mizahi malzemeyi konu edinen ve mizahın bir türü olan komedi, bir yandan insanın başkalarının budalalıklarına gülme zaafını yansıtırken diğer yandan insanın kendi yaşamında aynı yanlışları yapmamasını sağlamakla yükümlüdür. Komedi, bu yükümlülüğü yerine getirirken mizahın hiciv, espri, satir, şaka, halt, nükte, ironi vb. türlerinden yararlanır. Mizahın farklı türlerinden beslenen komedinin iki ana/önemli işlevi bulunmaktadır: Eğlendirmek ve eleştirmek/muhalefet etmek. Benzer şekilde mizahın da görünen yönünü, yani bedensel tepkisini oluşturan açık işlevini; keyif verme ve eğlendirme, eleştiri ve hoşgörü oluştururken gizli işlevini; başkaldırı, protesto ve tahrip etme, başarılı savunma mekanizması olma, yarar veya zarar verme, sorunlarla başa çıkma, dikkat çekme, hayata tutunma, fiziksel iyileştirme, sosyalleşme, gerilimi azaltma, savunma ve saldırı, toplumsal tarihin kod ve mesajlarını taşıma, kabullenmeme, itiraz oluşturmaktadır (Eker, 2014, s.30-71). Çalışmanın bu bölümünde komedinin Türk televizyonundaki dönüşümünde etkili olan faktörler iki alt başlık altında incelenecektir.

\section{Türk Televizyonunda Durum Komedisinin Dönüşümü}

Etkin bir kitle iletişim aracı olarak televizyonun, komedinin bahsi geçen iki önemli işlevinden ağırlıklı olarak eğlendirme işlevini kullanmayı tercih ettiği görülmektedir. Bu tercih elbette bilinçlidir. Zira televizyon o ilk yıllarındaki toplumsal işlevi de kapsayan işlevleri geride bırakmış ve artık sadece daha çok tüketimi teşvik eden ve eğlendirme amacını taşıyan bir aygıt haline gelmiştir. Komedi, ruhunda anarşist ve muhalif bir özellik taşısa da televizyonun, bahsettiğimiz bu dönüşümü nedeniyle, televizyonda yer alan komedinin de evrim geçirdiği söylenebilir. Bu anlamda televizyon komedisinin, evcilleştirilmiş bir tür olduğunu söylemek yanlış olmayacaktır. Anlam üretme sürecinin sıkı sıkıya denetlenmesi onu evcilleşmeye zorlamaktadır. Televizyon; kurulu düzenin, mevcut egemenlik biçim ve içeriklerinin savunu aracıdır (Mutlu, 1991, s.230). Erdoğan ve Alemdar'a göre televizyondan dünyaya açılan pencere, biçimlendirilmiş bir penceredir. Bu pencereden sunulan dünya ise günümüzdeki egemen ekonomik ve siyasal güçlerin çıkarlarının gerçekleşmesi yönünde düzenlenmiştir (Erdoğan ve Alemdar, 2001, s.195).

Televizyon komedisi için söz konusu olan durumun, gülmece dünyasının başat biçimi olarak adlandırılan durum komedisi özelinde de geçerli olduğu görülmektedir. Durum komedisinin evcilleştirilmiş televizyon komedi biçimlerine egemen olması, Mutlu'nun ifadesiyle şebekelerin 


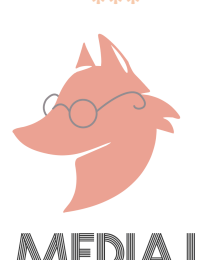

yığınsal duyguları formüle etme çabalarıyla bağlantılıdır. Mutlu'ya göre bu çabalara üç etken yön verir: "ilki programların izler kitle piyasasındaki durumlarıyla ilgili hesaplardır (puanlama ve pazar payı); ikincisi program maliyetleriyle ilgili hesaplardır, üçüncüsüyse programların gerçekleştirilmesinde beyin ve kol güçleriyle yer alanların, özellikle yazarların sınırlarıdır." (Mutlu, 1991, s.231-233). Türk televizyon tarihindeki yerli durum komedilerinin ilk örnekleri ile bugünkü örnekleri kıyaslandığında bu üç etken, günümüz durum komedileri için varlığını çarpıcı bir şekilde göstermektedir.

Yerli durum komedisinin ilk örneği olarak, 1974 yılında yayımlanmaya başlanan toplumsal taşlama türündeki Yaşar Ne Yaşar Ne Yaşamaz gösterilmektedir. Bu dizinin, içerik ve biçim olarak durum komedisinin özelliklerine uyumlanmaya çalıştığı ve bunu pek çok noktada başardığı görülmektedir. Zira, durum komedisi içerik ve biçim olarak sınırları çizilmiş muayyen bir türdür. Prime-time kuşağında gösterilen durum komedisi, (on beş - yirmi dakikalık ve bir saatlik örnekleri bulunmakla birlikte) genellikle otuz dakikalık bölümlerden oluşmaktadır. Her bölümdeki karakter ve mekân yapısı da düzenli ve değişmez bir özellik göstermektedir (Oğuz, 2002, s.10; Mutlu, 1991, s.255). Taflinger, çatışma yapılarına göre durum komedilerini üçe ayırır: Televizyonda en çok tercih edile tür olan; kişisel çatışmalara dayalı aksiyon temelli durum komedileri (actcom), ailesel çatışmalara dayalı olan karakter temelli durum komedileri (domcom) ve karakterlerin sosyal konulara karşı yaklaşımlarına dayanan fikir temelli durum komedileridir (dramedy) (Taflinger, 1996).

Türk televizyon tarihinde, 1974 yılından 2010'lu yıllara kadar olan süreçte, yerli durum komedilerinin gerek içerik gerekse biçimsel yönden durum komedinin özelliklerini yansıttığı görülmektedir. Örneğin, bu diziler arasından Kaynanalar (1974-2004), Ali Uyanık (1976), Kuruntu Ailesi (1983-2002), Kim Bunlar (1989), Kaygısızlar (1994-1998), Gülşen Abi (1994-1995), Ayrılsak da Beraberiz (1994-2004), Sıdıka (1997-2003), Yedi Numara (2000-2003), Dadı (2001-2002), Tatıı Hayat (2001-2004) ve Yarım Elma (2002-2003) gibi diziler, çatışma durumları ve süreleri açısından durum komedilerinin içerik ve biçimsel özelliklerine sahiptir.

2000 sonrası dönemde yerli durum komedilerinde içerik ve biçimsel açıdan yaşanan olumsuz nitelikteki dönüşüm, Türk televizyon kanallarında yayınlanan dizilerin sürelerinin -tür ayırt etmeksizin- uzamasıyla ve dönemin değişen toplum yapısıyla doğru orantılıdır. 2010'lu yıllara doğru yerli dizilerin süreleri, kırk beş dakikadan doksan dakikaya ulaşmış; bu durum da senaristler ve dizilerin set çalışanları tarafından protesto edilmiştir. ${ }^{8}$ Ancak süre krizi bu dönemde çözüme kavuşamadığı gibi bölüm süreleri birkaç yıl içerisinde 90 dakikadan 120-150 dakikalık seviyelere ulaşmıştır. ${ }^{9}$ Yaşanan bu değişimi durum komedisi özelinde örnekleyen dizilerden biri, senaristliğini Gülse Birsel'in üstlendiği Avrupa Yakası isimli dizidir. 2004 yılında ATV'de yayınlanmaya başlayan Avrupa Yakası, ilk üç sezon 45-60 dakikalık bölümlerle gösterilirken dizi, son üç sezonunda 80-120 dakika arasında değişen sürelerde yayınlanmıştır. Birsel'in Avrupa Yakası'ndan sonra senaristliğini üstlendiği Yalan Dünya (2012) ve Jet Sosyete

\footnotetext{
8 http://www.hurriyet.com.tr/gundem/dizi-setleri-ayaklandi-16617558 Erişim Tarihi: 19.12.2019

9 Dizi sürelerinin uzaması televizyon kanallarının izlediği yayın politikalarından kaynaklanmaktadır. 2000 sonrası dönemde yerli dramlar, yurt dışına satılmaya başlanmıştır. Dizilerin 120-150 dakikalık bir bölümü, yurt dışına 40-50'er dakikaya bölünerek olmak üç bölüm şeklinde satılmış; bir dizi bölümünden üç bölüm parası kazanılması hedeflenmiştir. Buna karşın komedinin evrensel olmayan yapısı, yerli durum komedilerinin yurt dışına satılmasında en büyük engeli oluşturduğu için yerli durum komedileri, dönemin pazar sistemi içinde kendine dramlar kadar yer edinememiştir.
} 


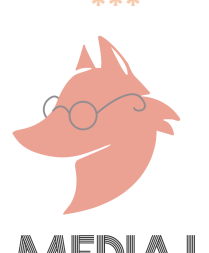

(2018) isimli diziler de her hafta 100-120 dakikalık bölümler şeklinde yayınlanmıştır. Bu dizilerden Jet Sosyete'nin televizyondan internet ortamına taşınması ve internette 45-50 dakikalık bölümler şeklinde yayınlanmaya başlaması ise durum komedilerinde gelinen noktayı özetlemektedir. Zira, her hafta 100-120 dakikalık bölüm yazmak komedinin biçimsel özelliğini kaybetmesi dışında içerik açısından da zayıflamasına neden olmaktadır. Örneğin Birsel, "... bir daha televizyona 100-120 dakikalık dizi yapmayacağım. Komedi 120 dakika olmaz. Dünyanın hiçbir yerinde böyle bir şey yok. Drama bir nebze yapılabilir ama komedi hiçbir şekilde yapılmıyor. Ben artık yoruldum, başka platformlarda buluşmak üzere." diyerek üretim sıkıntısını dile getirmiş ve artık televizyona dizi yapmayacağını açıklamıştır. ${ }^{10}$ Tüm bu süreç sonunda özellikle $2010^{\prime}$ lu yıllarda televizyondaki durum komedilerinin sayısı oldukça azalmış; komedi-skeç programlarının sayısında ise artış görülmüştür.

Dizi sürelerinin uzamasına ek olarak 12 Eylül 1980'de başlayıp, 2000 sonrası hızlı bir ivme kazanan dönemin değişen toplumsal yapısı da durum komedilerinin dönüşümünde etkili olmuştur. Bu dönemde eleştiriye ve mizaha olan tahammülün azalması sonucunda durum komedileri toplumsal sorunları, krizleri ele alan, onları hicveden bir tür olmak yerine, sistemle iyice bütünleşerek onun istediği insan tipine hizmet eden bir yapıya bürünmüştür. Sonuç olarak, kapitalist sistemin dinamikleriyle hâlihazırda evcilleştirilmiş bir tür olan durum komedisi gerek içerik gerekse biçimsel açıdan 2000'lerin Türk televizyonlarında bu sistem içinde iyice öğütülmüştür.

\section{Etkileşim İçindeki Türk Televizyon Komedisi}

Her medya aracı, daha altın çağını yaşadığı esnada ömrünü uzun tutmak ve kar etmeyi sürdürmek amacıyla farklı alanlarla etkileşim içine girer. Etkin medya araçlarından televizyonun da benzer bir yaklaşımla, başta tiyatro ve sinema olmak üzere pek çok alanla etkileşim içine girdiği görülmektedir. Araştırmanın bu bölümünde, yerli televizyon komedisinin etkileşim içinde olduğu alanlar örnekleriyle birlikte incelenecektir.

Mutlu, Türkiye'de televizyon yayıncılı̆ının başladığı dönemde, televizyonun sinemadan önce tiyatro ile etkileşim içinde olduğunu söyler (Mutlu, 1991, s.268). Halihazırda Türkiye'de yayınlanan ilk yerli durum komedisinin Aziz Nesin'in tiyatro oyunundan uyarlanan Yaşar Ne Yaşar Ne Yaşamaz olduğu göz önünde bulundurulduğunda televizyon komedisinin ilk olarak tiyatro sanatıyla etkileşime girdiğini söylemek mümkündür. Bu dönemde televizyondaki dizi ve program içeriklerindeki oyuncu gereksinimi de yine tiyatrodan karşılanmıştır. Başlangıç döneminden sonra, televizyon komedisinin tiyatroyla olan etkileşimi Olacak O Kadar (1986), Haşlama Taşlama (1993), Yaseminname (1994), ince ince ince Yasemince (1995), Bir Demet Tiyatro (1995) vb. durum komedisi ve komedi programlarıyla sürmüştür. Mutlu, televizyon komedisinin sinemayla da etkileşime girdiğini belirtmekle beraber televizyon komedisinde Türk Sineması'ndan devralınan bir anlatı geleneği olmadığını şu sözleriyle ifade eder:

Sinemadaki 'Adanalı Tayfur' (Öztürk Serengil), 'Turist Ömer' (Sadri Alışık) gibi tiplemeler televizyonda 'Ali Uyanık' (Ali Poyrazoğlu), 'Domates Güzeli' (Ayşen Gruda) gibi bazı komik tipleri en azından fikir düzeyinde etkilemişlerdir. Ancak televizyondaki bu tipler devamlılık gösteren bir

10 https://tr.sputniknews.com/turkiye/201904171038785623-gulse-birsel-bir-daha-televizyona-100-120-dakikalikdizi-yapmayacagim/ Erişim Tarihi: 19.12.2019 


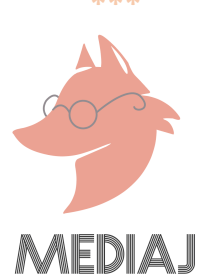

Cilt / Vol: $03-$ Sayı / No: $02 \quad$ | $\quad$ e-ISSN: 2757-6035

komedi biçimine dönüşmemiştir; böylesi bir biçimin oluşmasına da katkıda bulunamamışlardır (1991, s.266-267).

Televizyon ve sinema arasındaki etkileşimin en yoğun biçimde hissedildiği zaman dilimi ise 2000 'lere denk gelmektedir. Bu dönemde, televizyondaki komedi dizi ya da programlarıyla tanınırık kazanan isimlerin, aynı etkiyi sinemada da sürdürme girişimi başlamıştır. Öyle ki sinema kariyeri, televizyon kariyerinden önce başlayan ya da sinema filmlerinin yüksek izlenme oranına sahip olmasında televizyondaki komedi dizi ve programlarının etkisi bulunan isimler arasında Yılmaz Erdoğan, Ata Demirer, Gülse Birsel, Şahan Gökbakar, Ahmet Kural, Murat Cemcir, Şafak Sezer, Ezgi Mola ve Gupse Özay gibi isimler bulunmaktadır. Örneğin, senaristliğini ve başrolünü Şahan Gökbakar'ın üstlendiği, Türk Sinema tarihinin en çok izlenen serisi Recep ivedik serisi (2008-2019), Dikkat Şahan Çıkabilir (2005-2006) isimli skeç programından doğmuştur. ${ }^{11} \mathrm{Bu}$ örnek dışında 2000 sonrası için televizyonun kendisiyle ve özellikle sinemayla olan etkileşimini gösteren birçok örnek daha bulunmaktadır. Örneğin, sinemada Çok Filim Hareketler Bunlar (2010) ismiyle gösterilen yapım, Çok Güzel Hareketler Bunlar (2008) isimli skeç programından uyarlamadır. Çok Filim Hareketler Bunlar, bütünlüklü bir anlatı yapısına sahip bir film olarak değil, dokuz skeçten oluşan bir yapım olarak gösterime girmiştir. Benzer bir durum 2013'te yayınlanmaya başlayan Güldür Güldür Show isimli skeç programı için de geçerlidir. Güldür Güldür Show ekibi, bu programdan sonra Dedemin Fişi (2016) ve Cicim Babam (2018) isimli filmlerde yer almıştır. Sinema filmine uyarlanan komedi dizileri arasında ise Geniş Aile (2009) ve Emret Komutanım (2005) gibi diziler bulunmaktadır ${ }^{12}$. Buna ek olarak, Muro: Nalet Olsun Içimdeki Insan Sevgisi (2008) isimli komedi filmi ise Kurtlar Vadisi Pusu (2007) dizisinden doğmuştur. Film, dizideki Muro isminde yardımcı roldeki bir tipin o dönemde popülerlik kazanmasıyla ortaya çıkmış ancak filmin anlatısı sadece bu tip üzerine, Kurtlar Vadisi dizisinden bağımsız bir şekilde oluşturulmuştur. Bu oluşumlar arasından Şevkat Yerimdar film serisinde ise bu örneklerin tersine bir durum söz konusu olmuştur. Şevkat Yerimdar (2013) ve Şevkat Yerimdar 2: Bizde Sakat Çok (2015) filmleri, sinemada gösterime girdikten sonra 26 Mayıs 2017'de Fox TV'de dizi şeklinde yayınlanmaya başlamıştır (Türkavcı, 2018, s.77).

Sonuç olarak Türk televizyonculuğunda televizyon komedisi başlangıcından günümüze değerlendirildiğinde, televizyon komedisinin tiyatro ve sinema gibi alanlarla etkileşimi sonucunda dönüşerek Türk televizyonculuğuna has bir yapıya sahip olduğu ve sistemle iyice bütünleştiği görülmektedir.

\footnotetext{
11 Halihazırda 2000'lerde komedi-skeç programı sayısında artış görülmüştür. Bu programlardan doğaçlama komedi skeç programı türünde Anında Görüntü Show (2008-2009), Mahşer-i Cümbüş (2011), Buyur Bi'de Burdan Bak (20152018); yarışma formatında Komedi Türkiye (2015), Görevimiz Komedi (2016); komedi programı türünde Korsan TV (2001-2004), Dikkat Şahan Çıkabilir (2005-2006), Haneler (2009-2010); skeç programı türünde Çok Güzel Hareketler Bunlar (2008-2011), 5’er Beşer (2011), Insanlar Alemi (2012), Eğlendirme Dairesi (2015), Güldür Güldür Show (20132019), Geldim Gördüm Güldüm Show (2016), Acayip Tipler (2018) ve Çok Güzel Hareketler 2 (2018-2019) isimli programlar örnek gösterilebilir. Bu programların sayıca bu dönemde artmasında dizi sürelerinin uzaması ile skeç programlarının durum komedilerine kıyasla çok daha düşük maliyetle üretilmesi neden olarak gösterilebilir. Ayrıca bu programlar, üye sayısı onu bulan yazar ekipleri tarafından yazıldığı için programlarda üretkenlik konusunda durum komedilerindeki soruna benzer bir sıkıntı yaşanmamaktadır. Ancak programların mizahın eleştirel olma/muhalefet etme özelliği yerine, ağırlıklı olarak eğlendirme özelliğinden yararlanmayı tercih ettiği görülmektedir. Her ne kadar programlarda yoğun bir biçimde televizyon içeriklerine dair parodiler (evlendirme, tartışma, yarışma programları vb.) bulunsa da bunlar toplumsal taşlama ya da hiciv boyutuna ulaşamadığı için televizyonun kendisini yeniden üretmesine yol açmıştır.

${ }^{12}$ Geniş Aile dizisinden uyarlanan filmler; Geniş Aile: Yapıştır (2015), Geniş Aile 2 Her Türlü (2016) ve Geniş Aile Komşu Kızı (2019) iken Emret Komutanım isimli diziden uyarlanan film ise Emret Komutanım: Şah Mat (2007)'tır.
} 


\section{Çok Güzel Hareketler 2 ve Güldür Güldür Show İsimli Komedi Programlarında Toplumsal Cinsiyet Rollerinin Temsili}

Çok Güzel Hareketler 2, yapımcılı̆̆ını Necati Akpınar'ın (şirket: BKM), genel sanat yönetmenliğini ve sunuculuğunu Yılmaz Erdoğan'ın üstlendiği komedi skeç programıdır. Program, 2008 ile 2011 yılları arasında Kanal D'de yayınlanan Çok Güzel Hareketler Bunlar isimli programın devamıdır. Programda on üçü erkek, dokuzu kadın olmak üzere toplamda yirmi iki oyuncu bulunmakta; sahnelenen skeçler oyuncu kadrosu tarafından yazılmaktadır. Güldür Güldür Show ise, 2013 yılından itibaren Show TV'de yayınlanan komedi skeç programıdır. Yapımcılığını Necati Akpınar'ın (şirket: BKM), yönetmenliğini Meltem Bozoflu, sunuculuğunu Ali Sunal'ın üstlendiği programda on üçü erkek yedisi kadın olmak üzere toplamda yirmi oyuncu bulunmakta ve skeçler on kişiden oluşan senaryo grubu tarafından yazılmaktadır.

Araştırmanın bu bölümünde, amaçlı örneklem yöntemi doğrultusunda her iki programdan ikişer skeç grubu oluşturulmuş; toplamda 16 skeç incelenmiştir. Programlarda düzenli olarak bölümlü skeç sahnelendiği için örneklem oluşturulurken skeçlerden bir tanesinin bölümlü skeç olmasına dikkat edilmiştir. Örneklem olarak seçilen skeçlerdeki kadın, erkek ve LGBTIQ tiplerin sayısı içerik analizi yöntemiyle belirlenmiş, elde edilen veriler iki ayrı tabloda gösterilmiştir. Ardından skeçlerdeki kadın, erkek ve LGBTIQ cinsel kimliklerin nasıl temsil edildiği, skeçlerde öne çıkan mesajların neler olduğu (toplumsal cinsiyet kavramı üzerinden eleştirinin getirilip getirilmediği, ataerkilliğin ya da homofobik söylemin yeniden üretilip üretilmediği) sorgulanmıştır.

Tablo 1: Çok Güzel Hareketler 2 İsimli Programdaki Skeçlerde Yer Alan Tiplerin Cinsel Kimlikleri

\begin{tabular}{|l|l|l|l|l|}
\hline Skeç Adı & Skeç Sayısı & Kadın & Erkek & LGBTIQ \\
\hline $\begin{array}{l}\text { Açın Kapıyı 1- 10 } \\
\text { (Bölümlü Skeç) }\end{array}$ & 10 & 4 & 10 & - \\
\hline Semtsel Dönüşüm & 1 & 2 & 5 & - \\
\hline
\end{tabular}

Tablo 2: Güldür Güldür Show İsimli Programdaki Skeçlerde Yer Alan Tiplerin Cinsel Kimlikleri

\begin{tabular}{|l|c|c|c|c|}
\hline \multicolumn{1}{|c|}{ Skeç Adı } & Skeç Sayısı & Kadın & Erkek & LGBTIQ \\
\hline $\begin{array}{l}\text { Terapi (Bölümlü Skeç) } \\
\text { Küsler Barışıyor } \\
\text { Anlaşamayan Çift }\end{array}$ & 3 & 5 & 7 & - \\
\hline Gelin Adayları & 1 & 2 & 2 & 1 \\
\hline Ufak Tefek Yalanlar & 1 & 1 & 5 & - \\
\hline
\end{tabular}

\section{Açın Kapıyı İsimli Skeçteki Toplumsal Cinsiyet Rollerinin Temsili}

Skeç, program sunucusu tarafından "Çilekeş Nurgül ve evin kıyak babası Necdet'in hikâyesi." şeklinde anons edilerek sunulur. Skeçte Nurgül, ev kadını rolünde iken Necdet ise mesleği ve çalışma durumuyla ilgili herhangi bir bilginin verilmediği alkolik baba rolündedir. Çiftin Nesli ve Faruk isminde iki çocuğu bulunmaktadır. Skecin adının açın kapıyı olmasının sebebi, Necdet'in eve her gün alkollü gelip ev halkı tarafından kapıda bırakılması ve her skeçte apartmanı "Açın kapıyı!.." nidalarıyla rahatsız etmesinden dolayıdır. Skeçte, ataerkil bir çekirdek ailenin başından 


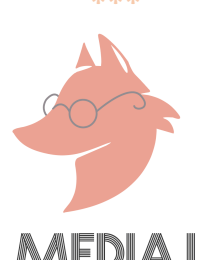

geçen maceralar her hafta bölümlü bir şekilde sahnelenmektedir. Ancak on bölümde öne çıkan ana konu, Necdet ve Nurgül çiftinin kızlarının kız isteme ritüelinden başlayıp evliliğe varan hikâyesidir.

Necdet alkol sorununa ek olarak, sorumluluk sahibi olmayan, ilgisiz bir eş ve baba rolündedir. $\mathrm{Tip}^{13}$, her on skecin her birinde çeşitli taşkın davranışlar sergiler: Eczaneye arabayla dalar, trafikte dünürlerinin önünü kesip onlardan para ister, iki kez gerçekleştirilen kız isteme esnasında olay çıkarır, bayram günü dünürlerini evden kovar vb. Necdet'in eşi Nurgül ise evin temizlik, bulaşık, ütü, yemek işlerine yetişmeye çalışan, kocasının her türlü "rezilliğini" sineye çeken ancak hastalandığında bile ev halkı tarafından umursanmayan özel alana hapsolmuş "çilekeş ev kadını"dır. Benzer şekilde Nurgül'ün dünürü de eşinin her türlü taşkınlığına göz yummak zorunda kalan, özel alana sıkışmış ev kadınıdır. Skeçteki diğer iki kadın tipten Nesli, öğrencidir. Ancak Nesli, özgürlüğü ağabeyi tarafından kısıtlanan, tek odağı evlenmek olan, dış görünüşüne düşkün biridir. On bölümlük skeçte tipin eğitim hayatına dair tek bir an gösterilmediği gibi tip, tüm bölümlerde kız isteme, nişanlanma, düğün gibi ritüeller içerisinde gösterilir. Faruk'un kız arkadaşı Melek ise bir işte çalışmaktadır ancak tipin mesleği skeçlerde belirtilmediği gibi, iş hayatına dair bir sahne de sergilenmemektedir.

Açın Kapıyı skecindeki tüm kadın tipler, hayatlarındaki erkeklerin yaşam tarzına, onların türlü taşkınlıklarına ve kısıtlamalarına uyumlanmaya çalışmaktadır. Tiplerden Melek, Faruk'un iş yerinde birine şiddet uygulamasına, kendisine yalan söylemesine edilgen tepkiler veren, Faruk'la ilişkisini ailesinden gizli yaşayan ve akşam olmadan eve dönmek zorunda olan biridir. On bölüm boyunca kadınların içinde bulundukları durumun eleştirildiği tek sahne Melek üzerinden gerçekleştirilir. Melek, kendisine sorulan sorulara kimi zaman annesi üzerinden yanıt vermektedir. Örneğin çay içip içmek istemediği sorulduğunda "Annem hava kararmadan çay içme dedi" şeklinde karşılık verir. Dolayısıyla tek bir an üzerinden yola çıkılarak, serinin kadınların toplumsal cinsiyet rollerine dair eleştiri getirdiğini söylemek mümkün değildir.

Skeçte toplamda on erkek tip yer almıştır. Bu tipler; Necdet, Necdet'in dünürü, Faruk, evin damadı Bilal dışında bu erkeklerin iş, aile ve arkadaş çevrelerinden kişilerdir. Skeçte, evin oğlu Faruk'un eğitimine dair bir bilgi verilmemesine karşın tip, lümpen davranışlar sergileyen, her girdiği işten bir günde kovulan (ya da işten istifa eden), sorumluluk sahibi olmayan, kız kardeşi ve eniştesinin özgürlüğünü kısıtlayan, aterkil biridir. Halihazırda serideki tüm erkek tipler, hayatlarındaki kadınlara zorluk çıkaran, onları "rezil eden", geleneklerine sıkı sıkıya bağlı, ataerkildir. Ancak seride tüm erkek tiplerin çıkardığı "rezillik"lerin hayatlarındaki kadınlar tarafından affedildiği görülmektedir. Zira tipler, seride "çocuksu erkek" özellikleriyle kurgulanmıştır. Erkek tiplerin "çocuksu erkek" olarak kurgulanmasının, tiplerin çıkaracağı tüm "rezillik"lerin affedilmesinin kolaylaştırılması adına yapıldığı görülmektedir. Öyle ki on bölüm boyunca bütün erkekler, yaşattıkları tüm sorunlar karşısında cezalandırılmazlar. Böylece, serinin

\footnotetext{
${ }^{13}$ Bu çalışmada, incelenen skeçlerdeki kahramanlardan tip olarak bahsedilmektedir. Kahramanlar karakter ya da tip olma özellikleriyle konumlanırlar. Zira karakterler çok boyutlu, tipler ise tek boyutludur. Tip kavramı, "insanları genellemesine yansıtan, kendine özgü kişiliği olmayan, daha çok bilinen kalıplardaki insanları gösteren oyun kişisi." anlamına gelir (Metin, And ve Nutku, 1966, s.107). Karakter kavramı ise sahne sanatlarında kişilikle eş anlamda kullanılmakta; kişiliğin başkaları tarafından, sosyal, toplumsal, etik olarak değerlendirilen 'görünüşleri'ni ifade etmektedir. (Bayrak, 2014, s.106). Karakter anlatı içerisinde sürekli bir değişim ve gelişim göstermesine karşın tip, anlatı boyunca aynı kalır ve belirli özellikleri korur (Aslan, 2007, s.38-39). Genellikle beş - on beş dakika arasında sahnelenen komedi skeçlerindeki kahramanlar da bu nedenlerden ötürü tip özellikleriyle karşımıza çıkmaktadır.
} 


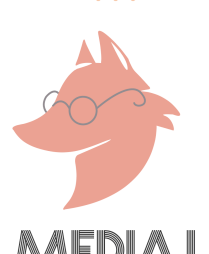

ataerkilliğe eleştiri getirmediği gibi onu yeniden üreten bir yapıya sahip olduğu görülmektedir.

Açın Kapıyı isimli skeçte on bölüm boyunca herhangi bir LGBTIQ rolüne rastlanmamaktadır. Zira, skeçte prototip şeklinde sunulan "Türk tipi" ataerkil bir ailede farklı cinsel kimliklere yer yoktur. Ataerkil toplumsal düzenin egemen değerleri, erkekliği de kadınlığı da sarmalayan niteliklerle örtüşür. Geleneksel aile yapısında erkekler meslek sahibi, karar veren olmalı, ailesini korumalı, yaşamsal sorunlarla baş etmeli dolayısıyla da güçlü olmalıdır. Kadınlar da bağımsızlıktan ve özgüvenden yoksun bırakılır. (Özkan, 2016, s.122). Doğal olarak sunulan; aslında ideoloji, toplum ve kültürden etkilenen cinsiyet rolleri, geleneksel toplumlarda kalıplara dönüşür ve bu toplumlarda farklı cinsel kimlikler yok sayılır ya da bastırılır. Bu yok sayma durumu, televizyonda yayınlanan bir skeç programında dahi, bilinçli ya da bilinçsiz bir şekilde varlık gösterebilir. Ancak toplumdan aldığını yine topluma sunan televizyon içeriklerinin toplumsal cinsiyet kalıp yargılarını yeniden ürettiği gerçeğini değiştirmemektedir. Öyle ki Açın Kapıyı serisinde de evin alkolik ataerkil babası, dünürüne hemen hemen her bölümde "puşt" şeklinde hitap ederek farklı cinsel kimliklere olan yaklaşımını dile getirmektedir. Sonuç olarak, on bölümlü Açın Kapıyı isimli komedi skecinin, toplumsal cinsiyet rollerine muhalif yaklaşmadığı ya da farklı bir bakış açısı sunmadığı gibi, ataerkil söylemi yeniden ürettiği görülmektedir.

\section{Semtsel Dönüşüm İsimli Skeçteki Toplumsal Cinsiyet Rollerinin Temsili}

Semtsel Dönüşüm isimli skeç, İstanbul'un kentsel dönüşüme tabii tutulan varoş mahallesinde geçmektedir. Skeç, adına karşılık olarak bir kentsel dönüşüm hikâyesinden ziyade, Barış ve Aslı isimli sevgili bir çiftin hikâyesi üzerinedir. Barış, İstanbul'un varoş bir semtinde (skeçte ismi belirtilmemiştir) yaşar. Aslı, Barış'ın arkadaşlarıyla tanışmak istediği için çift birlikte Barış'ın oturduğu semte gider. Ancak Barış, arkadaşlarından utandığı için onları Aslı ile tanıştırmayı istememektedir. Aslı, Barış'ın arkadaşlarıyla mahallede çıkan bir kavga esnasında tesadüfen tanışır. Barış'ın arkadaşlarının kendisine ve çevrelerine gösterdiği maganda davranışlarına dayanamayan Aslı, skeç sonunda bir süre görüşmemek üzere Barış'tan ayrılır.

Semtsel Dönüşüm isimli skeçte iki kadın, beş erkek tip olmak üzere toplamda yedi tip yer almıştır. Aslı dışında skeçteki diğer kadın tip, Aslı'nın arkadaşı Simge'dir. Barış dışındaki erkek tipler ise Barış'ın arkadaşı Fiko, Emrah; mahallenin entelektüeli Kâmil ve Fiko ve Emrah'ın saldırdığı bir mahallelidir (isim belirtilmemiştir). Skeçte, LGBTIQ rolüne rastlanmamaktadır. Skeçte, Fiko ve Emrah, maganda-lümpen davranışlar sergiler. Tiplerin erkeklikleri; kullandıkları cinsellik, şiddet ve argo anlamlar yüklü lümpen dilleri aracılı̆ıyla inşa edilmiştir. Her iki tipin de erkeklik tanımı, "delikanlı" gibi davranmak, tesbih taşımak, boyna muska ya da zincir takıp bağrı açık gezmek, olay çıktığında korkmadan olaya atlamak ya da devamlı kavga etmek şeklindedir. Tipler, karşı cinse kibar davranmayı erkekliklerine yediremediği için kılıbıklık olarak adlandırırlar. Ayrıca tipler, bir erkeğin entelektüel olmasını "dantel" olmakla eşdeğer gördüğünü belirtir. Öyle ki mahallerindeki Dantel Kamil'i sırf kız arkadaşlarına adres sorduğu için dövmeye kalkarlar. Skeç sonunda Aslı; Fiko ve Emrah, Kamil'i dövmeye kalktığı için Barış'ın arkadaş çevresiyle yapamayacağını anlar ve Barış'la bir süre görüşmek istemediğini söyleyerek gider. Bu noktada üç erkek tipin aslında toplumsallaşma etkisi yüzünden erkekliklerini göstermeye/yaşamaya ya da kanıtlamaya çalıştığı ortaya çıkar. Terk edildiği için üzülen Barış, "Siz benim çocukluk arkadaşımsınız diye ben size uyum sağlıyorum, ben aslında böyle değilim." der. Bu söze karşılık Fiko ve Emrah da -Barış gibi- birbirlerinden etkilendiklerinden dolayı maganda-lümpen davranışlar sergilediğini söyler. Böylece üç "semt çocuğu" farkında olmadan toplumsal cinsiyet rollerinin toplumsallaşma yoluyla aktarıldığı bilgisine erişir. Ancak üç tip de herhangi bir değişim 


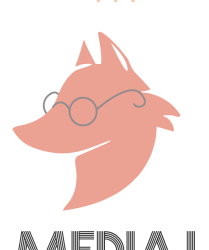

geçirmeden hayatlarına devam ederler. Ancak -yine de- bireylerin toplumsallaşma sürecinde kadın-erkek rollerini öğrendikleri bilgisinin verilmesi üzerinden, skeçte toplumsal cinsiyet rollerine (örtük bir biçimde ya da dolaylı yoldan) eleştirinin getirildiğini söylemek mümkündür.

\section{Terapi, Küsler Barışıyor ve Anlaşamayan Çift İsimli Skeçteki Toplumsal Cinsiyet}

\section{Rollerinin Temsili}

Terapi isimli skeçte, Naime ve Bilal isimli evli bir çiftin evliliklerindeki sorunları halletmek için gittikleri terapide başına gelenler konu edinir. Bu skecin ana kahramanları Naime ve Bilal, programın daha sonraki bölümlerinde Küsler Barışıyor ve Anlaşamayan Çift isimli skeçlerde yer alır. Ancak skeçlerde ana kahramanlar değişmediği ve konu aynılığını koruduğu için, skeçler araştırmada "bölümlü skeç" olarak incelenecektir.

Terapi'de Mesut isimli küs çiftleri barıştırmakla ünlü bir terapistin Naime ve Bilal'i barıştırma girişimi işlenmektedir. Mesut, yüzüncü çift olan Naime ve Bilal'i barıştırırsa Guinness Rekorlar Kitabı'na girecek ve büyük para ödülüne sahip olacaktır. Terapi skecinden sonra Naime ve Bilal, Küsler Barışıyor isimli skeçte Aşkım Kıpraşmak'la Küsler Barışıyor isimli canlı yayına çıkarak; Anlaşamayan Çift isimli skeçte ise karakola giderek barışmayı denemektedir. Naime ve Bilal'in barışma macerasının işlendiği üç bölümlü skeçte, beş kadın, yedi erkek olmak üzere on iki tip yer almaktadır. Serinin hiçbir bölümünde LGBTIQ'Iı tip yer almamıştır.

Üç bölümlük seride yer alan tüm tiplerin mesleklerinin toplumsal cinsiyet kalıpyargılarına (stereotypes) göre oluşturulduğu görülmektedir. Giddens, toplumsal cinsiyetin öğrenilmesinde -özellikle kişilerin cinsiyetlerine uygun meslek edinme sürecinde- öykülerin ve televizyonun etkisinden bahseder (Giddens, 2012, s.210). Tersine bir bakış açısıyla, öykü ve televizyondan öğrenilen bu kalıpyargıların medya aracılığıyla tekrardan sunulduğunu (ya da yeniden üretildiğini) söylemek mümkün olacaktır. Örneğin, Terapi skecindeki sekreter ile Küsler Barışıyor skecindeki astrolog rollerini kadın tipler canlandırır. Serinin ana kahramanı Naime, ev hanımı iken diğer iki tipin mesleği hakkında bir bilgi verilmemektedir ancak tiplerin skeçte eş kimliğiyle kurgulandığı görülmektedir. Benzer şekilde Anlaşamayan Çift skecinde de polis rolünü erkek tip canlandırmaktadır. Serinin ana kahramanı Bilal'in mesleğiyle ilgili bir bilgi verilmezken diğer erkek tiplerden ikisinin psikolog ve aşk doktoru mesleğiyle; geri kalan üç tipin ise skeçlerde eş kimlikleriyle kurgulandığı görülmektedir.

Serinin ana kahramanları Naime ve Bilal, gittiği her yerde (terapi, canlı yayın, karakol) âdâb-ı muaşeret kurallarını hiçe sayarak kavga edip birbirlerine ağır hakaretlerde bulunur. Örneğin Bilal, Naime'yi pert arabaya, böbrek taşına, kafes dövüşçüsüne benzetirken Naime ise Bilal'i tuvalet fırçası ve dışkıya benzetir. Skeçte, çiftin birbirinden bu denli tiksinmesinin nedeni olarak, her ikisinin de birbirinin cinsiyet rollerine uygun davranmadığını düşünmesi olarak gösterilir. Yani, Bilal, Naime'yi kadın rolüne uygun davranmamakla itham ederken Naime ise Bilal'i erkek rolüne uygun davranmamakla itham eder. Hatta Terapi isimli skeçte çiftin aşırılıklarına dayanamayan psikolog dahi bir süre sonra Naime'den "kadın gibi" davranmasını rica eder. Dolayısıyla seride, kadın ve erkek cinsiyet kimliği üzerinden toplumsal cinsiyet rollerinin sınırları çizilmiş olur. Örneğin Bilal, eve gidip kapıyı Naime açtığında onu bakımlı bir şekilde karşılamasını, gece yatarken yatakta güzel gözükmesini ve evin derli toplu olmasını ister. Böylece, erkeğin "dışarıdan eve gelen" kişi, kadının ise evde evi temiz tutan ve eşine bakımlı görünmek zorunda 


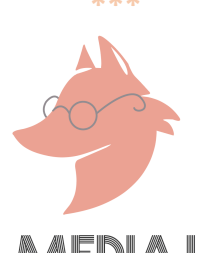

olan kişi olması, buradaki ataerkil aile düzenine gizlenmiş kamusal alan ve özel alan varlığını deşifre eder.

Seride kadın-erkek cinsiyet rollerine dair kalıp yargıların konu edindiği bir başka sahne ise Küsler Barışıyor isimli skeçte gerçekleşmektedir. Skeçte canlı yayına çıkan bir erkek tip: "Benim sorunum şöyle, eşim benim hanımcı, kılıbık ve omurgasız olarak görmesi beni. Ben onun her istediğini yaparak o kadar çok üzüyorum ki onu." diyerek aşk doktoruna eşiyle yaşadığı sorunu paylaşır. Canlı yayına bağlanan eş ise; "Bu adam benim her dediğimi yapıyor, her istediğimi alıyor, yanında ayrılmıyor, hiç yalan söylemiyor, sorun bu." şeklinde aşk doktoruna karşılık verir. Sahnenin devamında aşk doktoru çifti barıştırır. Sonuç olarak bu sahnede de "çiftler birbirlerinden kalıp yargılaşmış kadın-erkek rollerine uygun davranmasını bekler" konusu işlenir. Ancak her iki sahnede de kalıp yargılaşmış kadın-erkek rollerine eleştiri getirilmediği gibi, toplumsal cinsiyet rollerinin sadece eğlencelik bir mizah unsuru olarak kullanıldığı görülmektedir.

\section{Gelin Adayları İsimli Skeçteki Toplumsal Cinsiyet Rollerinin Temsili}

Gelin Adayları isimli skecin konusu programda şu şekilde sunulur: "Uzun bir aradan sonra gelinlikçide karşılaşan eski okul arkadaşları Naime ve Çiçek, birbirlerini ne kadar seviyor olabilirler? Damat adayları Kudret ve Kazım, kadınların rekabeti arasında kalınca ne gibi zorluklar yaşayacaklar?". Skeçte, evlilik hazırlığı yapan iki çift dışında Ozan isimli eşcinsel bir modacı bulunur. Ozan, skeçte birbiriyle rekabet halinde olan iki gelin adayına pahalı eşya satmak için uğraşır. Pahalı eşya alabilen gelin adayına yakın, alamayan gelin adayına aşağılayıcı davranışlar gösteren tipin skeçte bunun dışında bir işlevi yoktur. Tipin cinsel kimliği; aşırı feminen davranışlar sergileyen, diksiyonu bozuk, rüküş giyinen, agresif, eşcinsel stereotipiyle ele alınmıştır/kurgulanmıştır.

Skeçte gelin adayları Naime ve Çiçek'in mesleği ya da eğitimi hakkında bir bilgi verilmemektedir. Ancak her iki tip de sırasıyla gelinlik, düğün yeri, yüzük ve duvak konusunda sevgililerinden olan taleplerinden anlaşılacağı üzere karşı cinse bağlı, edilgen tipler olarak kurgulanmıştır. Gelin adayları, girdikleri rekabet sonucunda sevgililerinden gelinlik, yüzük, duvak ve düğün mekânı masrafları için yüz binlerce lira masraf yapmasını, gerekirse banka soymasını istemektedir. Öyle ki tiplerden Çiçek, sevgilisini "Bana bak Kazım, eğer bu düğün benim istediğim gibi olmazsa seni ağlatırım, süründürürüm." şeklinde tehdit eder.

Skeçteki her iki erkek tip ise -meslekleri belirtilmemesine karşın- eş adaylarının bütün istekleri yerine getirmek için çalışan, bütün yükü tek başına sırtlayan, kamusal alanın sıkıntı çeken erkekleri olarak kurgulanmıştır. Halihazırda skeçte açık bir biçimde eleştirilen durum, insanların kalıpyargılaşmış kadın-erkek cinsiyet rollerine uygun davranmaya mecbur bırakılmasının yol açtığı çatışmadır. Kazım ve Kudret, kendilerini sevgililerinin isteklerini yerine getirmek mecburiyetinde hissettikleri için banka soyarlar. Hatta Kudret, Çiçek'in düğünde özel bir gelin çiçeğine sahip olmayı istemesinden ötürü, botanik müzesinden çiçek çalar. Rekabetten yorulan Kazım; "Bana bak, artık şu kadın erkek eşitliği nerede ya, şu feminizm gelse de kurtulsak" şeklinde isyan ederken Naime; "Ya aşkım kız tarafım diye bana pahalı şeyler almak zorunda olmanla feminizmin ne alakası var, ayrıca bir feministiz" şeklinde karşıık verir. Ancak gelin adayları yüz elli bin TL'lik duvak için kavga edince damat adayları dügünü iptal eder. Skeç, gelin adaylarının terk edilmelerini umursamayıp eve kimin daha lüks araçla eve döneceği konusunda rekabet etmesiyle son bulur. Sonuç olarak, Gelin Adayları skecinde, LGBTIQ'lı stereotip üzerinden 


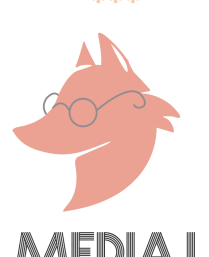

toplumsal cinsiyet rolleriyle ilgili herhangi bir eleştiri getirilmemesine karşın kalıpyargılaşmış kadın-erkek cinsiyet rolleriyle ilgili olarak, günlük hayatta sadece kadınların sıkıntı çekmediği; erkeklerin de zorluk yaşadığı vurgulanmaktadır.

\section{Ufak Tefek Yalanlar İsimli Skeçteki Toplumsal Cinsiyet Rollerinin Temsili}

Programda Ufak Tefek Yalanlar isimli skecin konusu "Sevgililerinden gizli bir araya gelip batak oynayan erkekler, sevgililerine ne gibi yalanlar söylüyorlar? Kazım'ın eşi Çiçek'in bir anda gelmesi batak gecesini nasıl mahvedecek?" şeklinde sunulmaktadır. Kazım, Mesut, Bilal, ibrahim ve Hayati isimli beş yakın erkek arkadaş, kâğıt oyunu oynamak için toplanmıştır. Kazım, arkadaş grubunun tek dürüst erkeği olarak bilinirken diğer erkekler, sevgililerine devamlı yalan söyler. Arkadaşları, Kazım'ın da gerçekte eşi Çiçek'e devamlı yalan söylediğini Çiçek'in Kazım'ı arayıp yanlarına gelmek üzere olduğunu söylemesiyle öğrenir. Çiçek'e her gün yalan söyleyerek arkadaşlarıyla farklı eğlenceler düzenleyen Kazım, yalanının ortaya çıkmaması için arkadaşlarını plan yapmaya zorlar. Kazım, Çiçek'e Bilal'in Mesude isimli bir kadınla evli olduğunu söylediği için Mesut'tan kadın kılı̆̆ına girerek Bilal'le rol yapmasını ister. Skeç boyunca gülme eyleminin sıkça ortaya çıkmasına neden olan bu plan, barındırdığı alt metinle toplumsal cinsiyet kalıp yargılarını deşifre etmektedir. Bu durum, skeçlerde yer alan kahramanların, iki erkeğin birlikte olduğunu söyleyebilme ihtimalinin olmadığını göstermekten ziyade, genel izleyici kitlesine hitap eden programda eşcinsel çiftlerin skeç konusu edilmeyip yok sayıldığını göstermektedir.

Kazım, eşine her gün birbirinden absürt yalanlar söylemesine karşın (arkadaşının düğününde opera şarkı söylemek için şan dersi almak vb.) Mesut ile Bilal'in sevgili rolü yapmasını; onlardan bu yalanı söylemelerini talep etmemekte/edememektedir. Bununla birlikte Kazım, eşine önceden Bilal'le Mesude'nin birbirini öpmeden duramadığını söylemiştir. Skeçte, Kazım'ın Mesut'la Bilal'den bebekleri olan karı-koca gibi davranmalarını istemesiyle beraber öpüşmelerini ısrarla istemesi, Bilal'le Mesut'un başta bundan hoşlanmayıp sonrasında öpüşmeyi sevmeye başlaması ise skeçte gülme eyleminin en yoğun yaşandığı anlardandır. Bu durum, -bilinçli ya da bilinçsiz bir tercih sonucunda- programda bireyin kendi cinsinden birini arzuladığının gösterilmesinin, ancak taraflardan birinin kadın kılığına bürünmesiyle mümkün olabileceği sonucunu göstermektedir.

Skeç sonunda, Kazım'ın cebinden batak oynarken çaldığı kartı düşürmesi, Mesut'un sinirlenip peruğunu çıkarmasına ve Çiçek'in gerçekleri öğrenmesine neden olur. Çiçek, Kazım'a bir ay ev gelmemesi gerektiğini söyleyip evi terk ettikten sonra tüm erkekler skeç sonunda bir araya gelip şarkı söyler: "Bu kızlar bizi manyak etti, tek derdimiz biraz eğlenmekti. Valla aldatmıyoz, dışarı çıkmıyoz, evde oturup kâğıt oynuyoz.". Skecin temasında, evlilikleri yüzünden arkadaşlarıyla sosyalleşemeyen, yalan söylemek zorunda kalan, özel alana sıkışmaktan ziyade "özel alanda sıkıştırılmış" erkeklerin varlığının altı çizilmiştir. Başka bir deyişle, skeçte erkeklerin de kamusal ya da özel alanda sorunlar yaşayabildiği söylenmiş ancak konuya ilişkin, gülme eyleminin daha kolay sağlanabileceği, "eğlenceli" bir tercih yapılmışır. Öyle ki skeçte tiplerin meslekleri, eğitimleri ya da sosyal sınıflarıyla ilgili bir bilgi de verilmemiştir. Bununla birlikte skeçteki kadın kahraman sayısının tek bir tiple sınırlı tutulduğu ve skeçte LGBTIQ tipe yer verilmediği görülmektedir. Skeçte, kadın-erkek cinsel kimliğiyle prototip şeklini alan ilişki temsilinde, LGBTIQ ilişki temsili dışarıda bırakılmış, bu temsil ancak kılık değiştirme trüküyle gülme eyleminin ortaya çıkması için kullanılmıştır. 


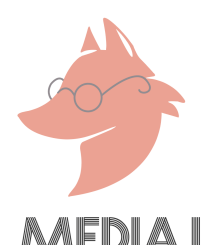

\section{DEĞERLENDIRME}

Televizyon, sinema ya da tiyatro fark etmeksizin komedi türündeki bir içeriğin kitlelere ulaştırılması, başka bir ifadeyle bir içeriğin üreticileri tarafından komedi ya da mizah yapma iddiasıyla kitlelere sunulması, o içeriğe komedinin yapısı birtakım gereklilikler/sorumluluklar yüklemektedir. Zira komedi, eğlendirme işlevinin dışında en etkin eleştiri/muhalefet etme araçlarından biridir. Komedi içerikleri gerek toplum gerekse medyadaki kalıp yargıları konu edinip yapısından aldığı güç ile onların temsilini eleştirel bir şekilde kitlelere sunabilir hatta örnek bir temsil alanı yaratabilir. Ancak televizyon dünyasının çarkları ve buna bağlı olarak kanalların güttüğü yayın politikaları ve içerik üreticilerinin içinde bulundukları dönemin sosyokültürel koşulları ile şekillenen üretim süreci, örnek bir temsilin oluşmasında engel olabilmektedir.

2010 'lu yıllarda yerli televizyon kanallarında öne çıkan türlerin başında eğlendirme işlevinin ön planda olduğu/tutulduğu komedi programları gelmektedir. Düşük maliyetle üretilmesi ve seyircinin yoğun ilgi göstermesi nedeniyle artış gösteren komedi programları arasından bu dönemde öne çıkan programlar ise Çok Güzel Hareketler 2 ve Güldür Güldür Show isimli programlar olmuştur. Araştırmada Çok Güzel Hareketler 2 ve Güldür Güldür Show isimli komedi skeç programlarından toplamda 16 skeç incelenmiştir. Çok Güzel Hareketler 2 isimli programdan seçilen skeçlerde LGBTIQ kimliğinde bir tipin bulunmadığı belirlenirken Güldür Güldür Show isimli programdan seçilen skeçlerde ise bir LGBTQ'lı tipin olduğu; bu tipin de skeçte stereotip olarak kurgulandığı görülmüştür. Çok Güzel Hareketler 2 isimli programdan incelemeye alınan skeçlerde toplam 21 tipten 15'inin erkek; altısının kadın olduğu, Güldür Güldür Show isimli programdan incelemeye alınan skeçlerde ise toplam 22 tipten 14 tipin erkek; sekiz tipin kadın olduğu görülmüştür.

Araştırma kapsamında incelenen 16 skeçte, toplumsal cinsiyet kalıp yargılarını yeniden üreten bir temsiliyet ve rol dağılımı olduğu gözlemlenmiştir. Skeçlerde kadın tiplerin özel alandaki çoğunlukla eş/eş adayı, anne, kız kardeş rollerinde kurgulandığı, erkek tiplerin ise -bazı skeçlerde erkek tiplerin toplumsal statüsü tam olarak belirtilmese de anlaşılacağı üzere- kamusal alanda, kadınlar üzerinde söz sahibi kişiler olarak kurgulandığı görülmektedir. İncelenen skeçlerden $A c ̧ ı n$ Kapıyı serisi ile Terapi, Küsler Barışıyor ve Anlaşamayan Çift serisi üzerinden ataerkilliğin yeniden üretildiği bulgusu ortaya konmuştur. Gelin Adayları ve Semtsel Dönüşüm skeçlerinde toplumsal cinsiyet rollerine dair dolaylı yoldan/örtük bir şekilde eleştiri getirildiği belirlense de tiplerin skeç sonunda herhangi bir değişim yaşamaması, eleştirinin amacına/yerine ulaştığına dair yargıda bulunulmasını zorlaştırmıştır. Diğer skeçlerden farklı olarak Ufak Tefek Yalanlar isimli skeçte, özel alanda sorun yaşayan erkeklerin konusu işlenmiş ancak bu skeçte de toplumsal cinsiyet kalıp yargılarına dair bir eleştiri görülmemiştir. Sonuç olarak, programlarda kalıpyargılaşmış kadınerkek cinsel kimliği dışındaki cinsel kimliklerin ağırlıklı olarak dışarıda bırakılması, toplumsal cinsiyet kalıp yargılarının yeniden üretilmesine neden olmuştur.

\section{KAYNAKÇA}

Aristoteles (2018). Poetika: Şiir Sanatı Üzerine. (A. Çokona ve Ö. Aygün, Çev.). İstanbul: Türkiye İş Bankası Kültür Yayınları.

Aslan, P. (2007). 90 Sonrası Türk Sinemasında Tip Karakter Ikilemi. Yayımlanmamış Yüksek Lisans Tezi. Dokuz Eylül Üniversitesi. 
Bayrak, T. (2014). "Sinemada Karakter Olgusu: Bir Karakter Oyuncusu Olarak Sadri Alışık", The Turkish Online Journal Of Design, Art And Communication, 4 (2), s. 105-122. Yayınları.

Caner, E. (2004). Kutsal Fahişeden Bakire Meryem'e Toprak ve Kadın. İstanbul: Su

Connell, R. W. (1998). Toplumsal Cinsiyet ve iktidar. (C. Soydemir, Çev.). İstanbul: Ayrıntı Yayınları.

Coştu, Y. (2009). Toplumsallaşma Kavramı Üzerine Sosyolojik Bir Değerlendirme. Dinbilimleri Akademik Araştırma Dergisi, 9 (2), 117-140.

Dökmen, Z. Y. (2009). Toplumsal Cinsiyet Sosyal Psikolojik Açıklamalar. İstanbul: Remzi Kitabevi.

Eker, G. Ö. (2014). Insan, Kültür, Mizah- Insanlık Tarihinde Mizahın Serüveni: Felsefi Bir Problem Olan Mizahtan Eğlence Endüstrisinde Tüketim Nesnesi Mizaha. (İkinci Baskı). Ankara: Grafiker Yayınları.

Erdoğan i. ve Alemdar K. (2001). Televizyon: Dünyaya Açılan Pencere, Ankara Üniversitesi Illetişim Fakültesi Yıllığı 1999, 169-97.

Eşigül, E. (2002). Cumhuriyet Dönemi Mizahı Üzerinde Değerlendirmeli Bir Bibliyografya Çalışması. Yayımlanmamış Yüksek Lisans Tezi. Ege Üniversitesi Sosyal Bilimler Enstitüsü, İzmir.

Giddens, A. (2012). Sosyoloji. (Birinci Baskı). İstanbul: Kırmızı Yayınları.

Kandiyoti, D. (1997). Cariyeler Yurttaşlar Bacılar Kimlikler ve Toplumsal Dönüşümler. İstanbul: Metis Yayınları.

Kolay, H. (2012). Geniş Ufuklar: Toplumsal Cinsiyet Eşitliği. İzmir: Ege Üniversitesi Kadın Sorunları Araştırma ve Uygulama Merkezi.

Kuruoğlu, H. (2014). Toplumsal Cinsiyet ve Medya. İzmir: Detay Yayıncılık.

Makal, O. (2017). Yönetmenleri ve Filmleriyle Gülmenin Sineması. İstanbul: Hayalperest Yayınevi.

Taner, H., And, M. ve Nutku, Ö. (1966). Tiyatro Terimleri Sözlüğü. Türk Dil Kurumu Yayınları.

Mutlu, E. (1991). Televizyonu Anlamak. İstanbul: Ayraç Yayınları.

Oğuz, G. Y. (2002). Televizyon Durum Komedilerinde Anlatı Yapısı. Kurgu Dergisi, $19,9-23$ 


\section{MEEDIAJ}

Özkan, Z. Ç. (2016). Geleneksel Türk Sinemasında Erkeğin Değişen İmgesi. Huriye Kuruoğlu (Der.), İçinde, Erkek Kimliğinin Değişemeyen Halleri (s.121-143). İstanbul: Nobel Yaşam

Saraç, S. (2013). Toplumsal Cinsiyet Yansımaları. Ankara: Atılım Üniversitesi Yayınları.

Scott, J. (2007). Toplumsal Cinsiyet: Faydalı Bir Tarihsel Analiz Kategorisi. (A. T. Kılıç, Çev.). İstanbul: Agora Kitaplığı.

Şener, G., Çavuşoğlu, Ç. ve Irklı, H. İ. (2016). Medya ve Toplumsal Cinsiyet. Feryal Saygılıgil (Der.), içinde, Toplumsal Cinsiyet Tartışmalar (s.165-187).

Sütcü, O. Y. (2016). Komedi ve Felsefe., Kuruoğlu, H. Ve Boz, M. (Der.), Medya ve Mizah (s.3-15). Ankara: Nobel Akademik Yayıncılık.

Türkavcı, E. (2018). Son Dönem Yerli Komedi Filmlerinde Bir Mizah Unsuru Olarak Lümpenlik. Yayımlanmamış Yüksek Lisans Tezi. Yaşar Üniversitesi Sosyal Bilimler Enstitüsü, İzmir.

Yalova, Y. (2002). Demokratikleşme Yolunda Toplumsal Cinsiyetin Ana Politikalara Yerleştirilmesi. TBMM Partiler Arası Uyum Komisyonu.

\section{Elektronik Kaynaklar:}

http://www.hurriyet.com.tr/gundem/dizi-setleri-ayaklandi-16617558, Erişim Tarihi: 19.12.2019

https://tr.sputniknews.com/turkiye/201904171038785623-gulse-birsel-bir-dahatelevizyona-100-120-dakikalik-dizi-yapmayacagim/, Erişim Tarihi: 19.12.2019

Taflinger, R. F. (1996). Sitcom: What it is, how it Works, http://www.wsu.edlJ.8080ftat1inger/sitexam.htmL.

TDK, https://sozluk.gov.tr/?kelime=C\%C4\%BONS\%C4\%BOYET, Erişim Tarihi: 19.12.2019 